\title{
INTERDISZCIPLINÁRIS ASSZOCIÁCIÓK A LÉLEKTAN ÉS HADVISELÉS TÉMÁVAL KAPCSOLATBAN - AZ V. NEMZETKÖZI INTERDISZCIPLINÁRIS KONFERENCIA TAPASZTALATAI
}

\section{Szerzők:}

Mező Ferenc (Ph.D.)

Eszterházy Károly Egyetem

Mező Katalin (Ph.D.)

Debreceni Egyetem

Szerző e-mail címe:

ferenc.mezo1@gmail.com

\section{Lektorok:}

Nemes Magdolna (Ph.D.)

Debreceni Egyetem

Szabóné balogh Ágota (Ph.D.)

Gál Ferenc Egyetem(Magyarország)

...és további két anonim lektor

\section{Absztrakt}

Ez a tanulmány az V. Nemzetközi Interdiszciplináris Konferencia (Debrecen, 2020. március 20.) szerzőinek (néha távoli) asszociációit mutatja be kutatási területük, valamint a hadviselés és/vagy a pszichológiai hadviselés témája között.

Kulcsszavak: lélektani hadviselés, hadviselés, kutatás

Diszciplinák: interdiszciplináris tudományok

\begin{abstract}
INTERDISCIPLINARY ASSOCLATIONS ABOUT THE THEME OF PSYCHOLOGY AND WAR - EXPERIENCES OF THE 5th INTERNATIONAL INTERDISCIPLINARY CONFERENCE
\end{abstract}

This study shows the (sometimes remote) associative thoughts of authors of V. International Interdisciplinary Conference (Debrecen, 20 March 2020) between their researching area and the theme of warfare and/or psychological warfare.

Keywords: warfare, psychological warfare, research

Disciplines: interdisciplinary

Mező Ferenc és Mező Katalin (2020): Interdiszciplináris asszociációk a lélektan és hadviselés témával kapcsolatban az V. Nemzetközi Interdiszciplináris Konferencia előadóitól. Lélektan és hadviselés - interdiszciplináris folyóirat, II. évf. 2020/2. szám. 9-22. doi: $\underline{10.35404 / L H .2020 .2 .9}$ 
Az V. Nemezetközi Interdiszciplináris Konferencia a Kocka Kör Tehetséggondozó Kulturális Egyesület főszervezésében valósult meg (a COVID-19 vírusbetegség okozta pandémia miatt online formában) 2020. március 15-2020. május 1. között. A rendezvény társszervezői (1. ábra): Debreceni Egyetem Tehetséggondozó Programja (Drs. Mándy Zsuzsanna), Debreceni Református Hittudományi Egyetem (Dr. Németh Áron), Digital Forensic Pro (Marian Svetlik), Eszterházy Károly Egyetem (Dr. Mező Ferenc), Magyar Tudományos Akadémia Debreceni Akadémiai Bizottság (Magyar Éva), MTA Miskolci Akadémiai Bizottság, Pszichológiai Szakbizottság (Dr. Hanák Zsuzsanna), Nagyszombati Egyetem (Dr. Ildikó Psenáková), Partiumi Keresztény Egyetem (Dr. Gál Katalin), Professzorok az Európai Magyarországért Egyesület (Dr. Koncz István), Újvidéki Egyetem (Dr. Horák Rita), K+F Stúdió Kft. (Dr. Mező Katalin).
Az eseményen tizenhat ország 274 résztvevője 202 prezentációval szerepelt. „A szerteágazó tudományterületekről érkező témák közötti összekötő kapocsként a szervezők nyilvános kérdés formájában többek között arra kérték a résztvevőket, hogy legalább egy gondolat erejéig válaszoljanak arra kérdésre, hogy: »Mi a kapcsolat a prezentációja és a hadviselés vagy a lélektani hadviselés között? «" (Mező K. és Mező P. D., 2020, 112.).

A rendezvény során a már említett 202 prezentáció 274 szerzőjének volt lehetősége asszociációt találni a konferencián bemutatott saját kutatási témája és a hadviselés, lélektani hadviselés témja között. Noha e két témakör valóban lehetőséget ad az inter-, illetve multidiszciplináris megközelítésnek, mégis mindössze 35 (17\%) értékelhető (valódi asszociációt kifejező) válasz érkezett (a „,nincs kapcsolat”, „,nem tudom” értelmű válaszokat nem tekintettük értékelhetőnek).

1. ábra: a konferencia résztvevoöi köre országonként, s szervezoói köre intézményenként (forrás: Mező K. és Mezô" P.D., 2020, 112. о.)

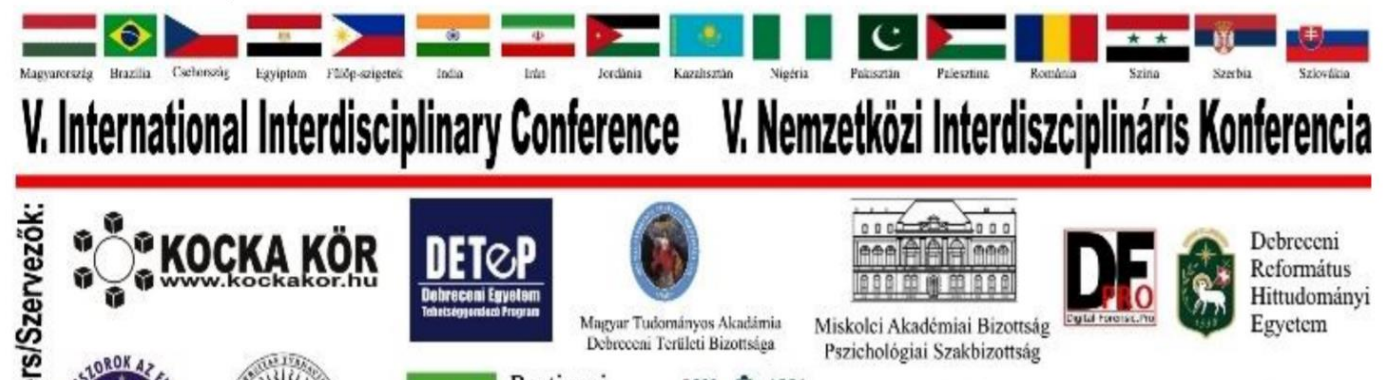

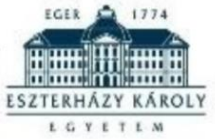

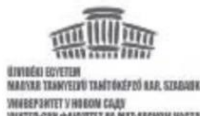

K+F STÚDió Kft. 
Ez az ideálisnak tekinthető minimum 99\%os (a potenciális 202 válaszból 200) értékelhetô válasz adásának tendenciájához képest igen csekély aránynak tekinthetô. Az értékelhető válaszok megfigyelt (35 válasz $=17 \%$ os) és az ideálisan várható (200 válasz $=99 \%$ ) számának gyakoriságát tekintve: khi-négyzet $=13610,561, \mathrm{df}=1, \mathrm{p}<0,001)$. De még egyfajta véletlenszerűséget feltételezve is szignifikáns a különbség az ,értékelhetô:nemleges vagy hiányzó” válaszok várható 50:50\%os eloszlása és a megfigyelt 17:83\%-os gyakoriságok között (khi-négyzet $=86,257, \mathrm{df}$ $=1, \mathrm{p}<0,001)$.

Az alacsony válaszadási tendencia mögött feltételezhető (nem valószínűségi vagy fontossági sorrendben, hanem mindössze felsorolásszerűen):

a) egészségügyi akadályoztatás: sajnos a konferencia időszakában már világszerte kimutatható volt a COVID-19 vírusbetegség, s ez, vagy akár más betegségek, balesetek, szisztémás rendellenességek akadályozhattak néhány potenciális válaszadót. Kutatásmódszertani szempontból a jövőben ez a válaszadási időszak meghosszabbításával kezelhető a jövőben,

b) érdektelenség a témával kapcsolatban. A jövőben a háború és lélektani hadviselés témája iránti érdeklődésfelkeltést célzó, konferencia előkészítő prezentációkkal, felhívásokkal célszerű élni.

c) érdektelenség a válaszadással, aktív konferencia jelenléttel kapcsolatban. Általános szemléletformáló tevékenység mellett a rendezvényszervezők konkrét intézkedése lehet, hogy a részvétel diját, illetve a konferencia részvételt és/vagy annak igazolását az aktív konferenciarészvételhez kötik (ahol az aktivitás nem csak a saját prezentáció közreadására vonatkozik, hanem a szakmai konzultációkba, vitákba történő bekapcsolódásra is).

d) a potenciális válaszadó valóban nem lát kapcsolatot kutatási témája és a hadviselés, illetve lélektani hadviselés témakör között. Jelen tanulmány Szerzőinek felvállaltan elfogult álláspontja szerint: a hadviselés témaköre annyira tágkörű, hogy minden tudomány-, illetve múvészeti terület felől közelíteni lehet hozzá. Hosszabb távú és átfogóbb, általánosabb célkitűzésként a jövőben célszerū a (távoli) asszociációs képesség és a holista látásmód, illetve a multi- és interdiszciplináris orientáció fejlesztésére figyelmet fordítani a köznevelésben, felsőfokú képézésben és a kutatóvá nevelés posztgraduális színterein (doktori képzésben, tehetséggondozó- és kutató múhelyekben). Rendezvényszervezési szempontból pedig jelen tanulmányhoz hasonló példatárak segíthetnek a potenciális válaszadóknak az interdiszciplináris asszociációk létrehozásában.

A továbbiakban a beérkezett válaszokat foglaljuk össze rövid elemzéssel, megjegyzésekkel kísérve. Hét asszociáció az orvostudományok területével kapcsolatban érkezett, két választ a környezettel foglalkozó szekcióból kaptunk, négy lehetséges kapcsolódási pontot jeleztek a pedagógia/vallás/társadalom szekció előadói, 
nyolc asszociáció kötődik a tehetség témakörhöz, a mesterséges intelligenciához négy kapcsolódási pontot jeleztek, nyolc művészeti, illetve történelmi megközelítésű válasz érkezett és a család, közösség, jog és gazdaság témákat felölelő szekcióból két válasz érkezett be.

\section{Az „Egészség és orvostudomány” (Health and Medicine) szekció résztvevői által adott válaszok}

Baksa és tsai (2020) a szem szaruhártyájának regenerációja esetében time-lapse videomikroszkópos megfigyelés révén vizsgálták a szén nanocsövek aggregációjának hatásait. A „time-lapse videomikroszkópos megfigyelés nem csak sejtszintű, hanem egyéb változások (például hadászati tevékenységek, hadsereg mozgásának megfigyelése, lőfegyverből kilőtt golyó repülési pályájának meghatározása stb.) hosszútávú megfigyelésére is alkalmas napokon keresztül, akár percenkénti lebontásban örökítve meg azokat. Végül ezen adatok digitális képanalízissel kiértékelhetők" - jegyzi meg Baksa és tsai. (2020, 8. o.).

A time-lapse videomikroszkópiát alkalmazta újonnan szintetizált nukleozid analógok citotoxikológiai vizsgálata során Polyák (2020) is. E módszer hadászati alkalmazási lehetôségével kapcsolatban megjegyzi, hogy: a kutatása során „...használt time-lapse videomikroszkópia nem csak a sejtek megfigyelésére használható, hanem például hadászati tevékenység hosszútávú megfigyelésére és a különböző hadseregek mozgásának elemzésére" is (Polyák, 2020, 52. o.).

Egu, Kalmár és Király (2020) olyan (mikrorészecskékből hatóanyagot felszabadító) gyógyszeradagoló rendszer fejlesztését kutatják, amely fokozhatja a tumorsejt növekedése ellen ható gyógyszerek hasznosulását, így növelve a terápiás hatást, s csökkentve a nem kívánt mellékhatások előfordulásának valószínűségét. Megjegyzik, hogy a lélektani hadviseléshez hasonló, ám a gyógyítás érdekében alkalmazott tervezett pszichológiai hatások közvetett eszköze lehet a kemoterápia (Egu, Kalmár és Király, 2020, 15. o.): „a betegek bizalmát növelheti például, ha a haj ép marad vagy kevésbé fogyatkozik meg a kemoterápia során".

Gyenes (2020) Mer Tirozin Kináz hiányos egér modell felhasználásával vizsgálja a csökkent izomregenerációt. Felvetése szerint: „A hadviselésben is fontos szerep jut az izomregeneráció folyamatának. A kutatás eredményei azon a területen is hasznosíthatók" (Gyenes, 2020, 19. o.).

Hinnah (2020) a TGF- $\beta$ útvonal változását elemzi Alzheimer-kór kapcsán. Az Alzheimerkór esetében az emberi test leépülése történik meg, mely jellemző neurológiai tünetekkel jár (Hinnah, 2020, 22. o.): „Először az enyhébb tünetek (afázia, ataxia) jelentkezésekor bekorlátozódik az egyén önmegvalósítási képessége, majd a folyamatosan egyre széleskörűbb ápolásra szoruló egyén a betegségstátusz fokozódásával elveszti környezete tiszteletét. Alzheimer-kórban fokozatosan szűnik a világban való orientációja az egyéneknek, már nem értik meg a körülöttük zajló legegyszerűbb összefüggéseket sem, ami miatt elvesztik biztonságérzetüket, szorongóvá válnak, továbbá gyakoriak a dühkitörések is. A betegség végstádiumában az egyén képtelenné válik a legalapvetőbb fizikai szükségleteinek kielégítésére, az Alzheimer-kór teljes győzelmet arat a bénult, inkontinens, mosdatásra és 
etetésre szoruló betegen" - írja Hinnah (2020, 22. o). Ehhez füzhetjük hozzá, hogy (bár erre nincs ismert történelmi példa, de elvileg) egy hadsereg Alzheimer-kórra jellemző pszichoneurológiai tünetképződéssel is járó „leépítése" akár a lélektani és biológiai hadviselés tágabb kontextusában is értelmezhető lehet.

Csontos (2020) az alsó végtag sérülésmintáit elemezi, valamint az és izomnyújthatóságra irányuló vizsgálatokat végez labdarúgást, illetve vízilabda sportot folytatók körében. A sport, hadviselés, valamint lélektani hadviselés között a következő kapcsolatot látja (Csontos, 2020, 13. o.):

1. A sportsérülésekről szóló vizsgálatok felhasználhatók a katonák rehabilitációja során, tekintve, hogy „A hadviselés általában fizikai megterhelést is jelent a katonák számára, amely mozgásszervi problémákat is okozhat.";

2. A sportolókat/katonákat érő (spontán jelentkező vagy szándékosan előidzett) lélektani terhelés is okozhat mozgásszervi panaszokat: „A labdarúgóknál és a vízilabdások esetében előfordulhat...” e jelenség, „....aminek következtében a motiválatlan sportoló elhanyagolhatja a megfelelő nyújtást, ami sportsérüléshez vezethet."

Lepp és Némethné (2020) kosárlabdázók körében célozták meg a scapularis diszfunkció, valamint a törzs-alsóvégtag stabilitásának vizsgálatát, intervencióját. A téma pszichológiai hadviseléssel való kapcsolatának megtalálását megkönnyíti, hogy a lélektani hadviselés napjainkban már nemcsak a hadtudomány, hanem például a sport kontextusában is alkalmazott kifejezés. A kosárlabda esetében például „A pszichológiai hadviselés lényege, és célja a másik csapat elterelése, a pánik keltése, szeparáció, (az összetartás leépítése) a domináns fél kitartásának megtörése. Így a csapat tagjai elbizonytalanodik, és könnyebb győzelmet aratni felettük" - írja Lepp és Némethné (2020, 32. o.), s hozzáteszik, hogy pszichológiai nyomás azonban „...szavak nélkül, a helyzet okozta stressz és kétségbeesés által is kialakulhat, akár egy éles helyzetben is, ahol az izgalom az eredmény rovására is mehet. A kosárlabda lényege a csapatok szabályszerű mérkőzése, ami nem csak a labda kosárba juttatására, hanem a csapatok közötti összhangra és a közösség erejének kimutatására is törekszik. A labda kosárba dobása önmagában nem teszi a csapatot nyertessé, de a (... pszichostressz beszúrás jelen tanulmány Szerzőitől) próbájának kiállása annál inkább”.

\section{A „Környezet” (Environment) szekció előadói által adott válaszok}

Szatmári (2020) a száradásos repedezést vizsgálja. Hadtudománnyal való kapcsolódási pontként jelöli meg, hogy: „A repedési jelenségek vizsgálatának egyik ága a kontrollált repedési mintázatok elemzése. Az ilyen kutatásokkal új, mechanikailag ellenállóbb anyagokat lehet kifejleszteni, melyeket a hadászat, hadiipar felhasználhat" (Szatmári, 2020, 61. o.).

Uzonyi (2020) infrastrukturális, szociális és biológiai hálózatokon, valamint random gráf modelleken keresztül vizsgálta a Taylor-féle hatványtörvényt. Eredményei hasznosíthatók lehetnek akár egy hálózat különböző csoportjainak tagjai közötti zajló lélektani hadviselés elemzésében. 


\section{A „Pedagógia, vallás és társadalom” (Pedagogy, Religion and Society) szekcióból érkezett válaszok}

Kovács (2020) erényelméletekkel, szúkebben ítélkezéselmélettel foglalkozik írásában. Témája és a hadviselés közötti párhuzamot a háború során kiadott parancsok alapján végrehajtott katonai cselekmények háború utáni megítélése vonatkozásában látja: „Rendkívül összetett kérdés az ilyen cselekmények megítélése ítélkezéselméletei szempontból is. Kérdéses, hogy mikori jogszabályokat kell alkalmaznunk, mikor igazságtalan egy jogszabály, engedelmeskedhetünk az igazságtalan jogszabályoknak, miért engedelmeskedünk egyáltalán vagy, hogy a parancs mentesít-e az erkölcsi felelősség alól?” (Kovács, 2020, 28. o.).

Sáfrány Judit (2020) az iskolai környezetben jelentkező szorongásos tünetegyüttesre fókuszál művében. Tágabb értelemben azonban „A szorongásos tünetegyüttes a stresszhelyzetben fellépő debilizáló vagy facilitáló jellege alapján értelmezhető a rendvédelemben dolgozó hivatásos személyek esetében. A poszttraumás stressz zavar kifejlődésére az extrém félelmi (szorongásos) reakció hajlamosít, ami a gyakori veszélyhelyzeteknek kitett személyek esetében fokozott figyelmet igényel." - írja Sáfrány (2020a, 55. o.). Sáfrány (2020b) a szorongás és a teljesítmény kapcsolatát is vizsgálja. Megjegyzi, hogy a „Katonák, tűzoltók és rendőrök körében az extrém distressz tapasztalatok előre jelezhetik a poszttraumás stressz szindrómát (PTSD-t). Munkájuk hatékonyságát a szorongás is befolyásolhatja" (Sáfrány, 2020b, 56. o.). Hozzáteszi még, hogy megfelelő kiképzés segíthet a stressz kezelésében, a szorongás enyhítésében, és a (veszélyes helyzetekben is) hatékony viselkedésben.

A tanári kompetenciák alakulását a drámapedagógia szemszögéből közelítő kutatása kapcsán a hadviselés, lélektani hadviselés témakörét Varga-Csikász (2020, 71. o.) a kiképzés aspektusából ragadja meg: „A drámapedagógia és a színházi nevelés eszközei „mintha” helyzetet teremtve lehetőséget adnak olyan dolgok utánzására, amikkel már találkozunk, és olyanokra is, amikkel még nem - ezek megjelenítésének csak a fantázia szabhat határt. A szerep védelmet nyújt a játszóknak, ezért akár a kérdésben említett témák bemutathatók a dráma eszközeivel. Például, egy haditudósító munkája során felmerülő lélektani nehézségek feldolgozhatók a tanítási dráma keretein belül."

\section{A „Tehetséggondozás és gyógype-} dagógia" (Talent Development and Special Education) szekció előadóinak asszociációi a témával kapcsolatban

Fábián Fruzsina és Varga Boglárka (2020) zenei téren vizsgálja a tanulásban akadályozott gyermekeket. E kutatási téma lélektani hadviselési vonatkozásaként felvetik, hogy „A zene által érzelmileg befolyásolhatóvá válhatnak az emberek" (Fábián és Varga, 2020, 16. o.), valamint azt, hogy a zenei nevelésnek hatása lehet az önbecsülésre és az önmegvalósítási igényre is.

Horváth László (2020, 24. o.) a Csáti Refi tehetséggondozó program potenciális lélektani hatásait taglalva felveti, hogy egy sikeres, eredményes tehetséggondozó kezdeményezés a konkurens intézmények körében körében akár azt is eredményezheti, hogy „A program 
eredményeit látva a környező iskolákon úrrá lesz a rémület."

Mező Ferenc (2020) a K+F Stúdió által alapított és fenntartott és a Nemzeti Tehetség Program által támogatott (azonosító: NTPPKTF-19-0002) „Innovációs Stúdium” tehetséggondozó program kapcsán jelzi, hogy: „Sajátos módon a technikai fejlettség/fejlődés szoros kapcsolatban áll a háborúkkal: ezek kölcsönösen meghatározzák egymást. Adott technikai fejlettség/adottság mellett csak meghatározott stratégiai/taktikai lehetőségek állnak rendelkezésre. A hadi megrendelések innovációt ösztönzők is egyben. A hadi innovációk másrészt polgári célokat is szolgálhatnak. (...) A lélektani hadviselés mint nem kinetikus hadviselési forma erôsokszorozó hatású nem halálos fegyver lehet.” (Mező F., 2020, 39. o.). Megjegyzés: a Stúdium működtetője, egyben a Lélektan és hadviselés című ingyenesen elérhetô (Open Access) e-folyóiratnak a kiadója (a lap a www.kpluszf.com honlapon keresztül érhető el).

Mező Katalin (2020) „Hölgyek a tudományban” program bemutatásakor (alapító, megvalósító: K+F Stúdió; támogató: Nemzeti Tehetség Program, azonosító: NTP-NEER19-0016) felveti, hogy napjainkban már hölgyek is elmélyülhetnek a hadtudományokban, így akár a lélektani hadviselés terén is szerezhetnek tapasztalatokat vagy kutathatnak éppen. Vagy éppen: a nők, ezen belül a katonanők is a lélektani hadviselés alkalmazói vagy célcsoprotjai lehetnek.

A kognitív képességek vizsgálatára fejlesztett S.M.ART művészeti mérőeszköz rendszer a K+F Stúdió innovációja (a fejlesztés a Magyar Képzőművészeti Egyetem által elnyert EFOP-3.2.6-16-2016-00001 projekt keretében valósult; Mező Ferenc és Mező Katalin, 2020). Az S.M.ART tesztek a kognitív képességeket feltérképezését (is) szolgálják, amiről tudni illik, hogy „...a kognitív képességek mérésének kezdete katonai múlttal rendelkezik. Az első intelligenciateszteket például a hadsereg alkalmazta a világháborúk idején” (Mező és Mező, 2020, 40. o.). De: az S.M.ART. tesztrendszer a gyermekekre (és nem a felnőtt katonákra) koncentrál, és felhasználói a tanárok és iskolák lehetnek elsősorban (és nem a hadsereg).

Mező Kristóf Szíriusz (2020) a jövő gépjármű fejlesztési lehetőségeit körvonalazza. Megjegyzi, hogy: „A műszaki technikai fejlődés és a hadviselés kölcsönhatással vannak egymásra. A jövő járművei így vélhetően hatással lesznek a jövő hadviselésére és viszont. Másrészt: a lélektani hadviselés eszközei is lehetnek a jövő járművei: zajokat, szövegeket, hang- és képfelvételeket továbbíthatnak, amelyek befolyásolhatják a harcoló felek érzelmeit, gondolkodását, viselkedését" (Mező Kristóf Szíriusz, 2020, 42. o.).

Molnár Alexandra (2020, 46. o.) tanulásban akadályozott gyermekek tanulásra motiválásának szempontjából jegyzi meg, hogy: „Ha nem jó módszert alkalmaz a pedagógus, akkor a gyermek bepánikolhat és nem lesz hatékony a tanulása". A tervezett lélektani hatáskeltésnek pedagógiai a szempontból a szorongás, „pánikolás” elkerülésére, kezelésére kell irányulnia.

Zsemján Eszter (2020) a tanulásban akadályozott tanulók integrált, inkluzív nevelésére vonatkozó kutatása tekintetében megjegyzi, hogy a lélektani hadviselés témaköre kapcsolódhat az integrációhoz, inklú- 
zióhoz is. „Ezeknél a pedagógiai formáknál, csak úgy, mint a lélektani hadviselésnél is figyelembe kell venni a különböző pszichológiai jegyeket. Pl. Vajon milyen hatással lesz egy tanulásban akadályozott gyermekre az, hogy ha többségi iskolába helyezzük? Vajon tényleg jól fogja magát ott érezni? Vajon tényleg boldog lesz?" (Zsemján, 2020, 75. o.).

A „Mesterséges intelligencia és informatikai kultúra" (Artificial Intelligence and IT Culture) szekcióbeli előadók kapcsolódása a témához

Csukonyi és Papp (2020) a sportpszichológia szerepét elemezi az e-sportban. Mindennek hadtudományt érintő vonatkozása például, hogy a debreceni katonai középiskolások körében alakult meg az egyik első magyarországi e-sport szakosztály, ahol „egy teljes e-sport kurzust végeztek a diákok, amely alapja lehet a későbbi sikeres munkavégzésüknek, a mesterséges intelligenciával való együttműködésüknek" (Csukonyi és Papp, 2020, 14. o.).

Krek (2020) a klasszikus szerepjáték napjainkban történő „újjáéledését” tanulmányozza (ez az újjáéledés például a videojátékok, számítógépes játékok terén figyelhető meg). Mint Krek (2020, 30. o.) megjegyzi, e műfaj inkább köthetô a szórakoztatóiparhoz és általában véve a populáris kultúrához, azonban „Létezik egy olyan ága a videojátékoknak, amelyet a világ vezető katonai kiképzőrendszerei is felhasználnak, ezek azonban az ún. serious gaming ernyőterminussal foghatóak össze".

Pšenáková (2020a,b) szerint a számítógépen (is) tárolt adataink védelme napjaink nagy kihívása közé tartozik. Az adatlopást, adatcsalást feltételező támadások ugyanakkor nemcsak technikai jellegűek lehetnek, hanem előfordulhat, hogy (akár informatikai rendszerek eszközként történő felhasználásával) pszichológiai manipulációt alkalmaznak az információszerzés érdekében, hogy az áldozat bizalmába férkőzzenek, s személyes, bizalmas adataihoz jussanak. Mint Pšenáková (2020, 53. o.) megjegyzi „,mivel pszichológiai manipulációról van szó (...) található közös kapcsolat" az informatikával, illetve adatvédelemmel.

Roskó Tibor (2020) három év távlatában tekinti át a mesterséges intelligenciára irányuló fejlesztéseket, s többek között azok (MI vezérelt drónokkal történő) hulladékkezelésben való felhasználási lehetőségeit. Mint írja: „...az alkalmazott technológiák, például, felderítő drónok alkalmasak lehetnek megfigyelésre is" (Roskó, 2020, 54. o.).

\section{A „Müvészet és történelem” (Art and} History) szekció előadói által adott válaszok

Lengyel Erik (2020) a zeneművek (részletek) háborús hangvételében látja a kapcsolatot a zene és a hadművészet között.

Mátyus (2020) érdeklődésének központjában a mesének a gyermeki lélekre gyakorolt hatása áll. Sokrétű kapcsolatot fogalmaz meg a mese, a hadviselés és a lélektani hadviselés között: „Egyféle »harcnak« tekinthető az a folyamat, amikor a gyermeki lélek elkezdi feldolgozni az adott mese történéseit. A tapasztalati és az elképzelt valóság között zajlik a harc a gyermekben. A hadviselésben példát láthatunk olyan modellre, miszerint fel 
kell mérni a »terepet«, az ellenség lehetséges cselekvéseit. Az ellenség megismerésére példát kínálhat a tündérmese, tréfásmese, és az állatmese is. Továbbá segít a különböző technikák bevetésére, túljárni az ellenség eszén. A »lélektani hadviselés« lezajlódhat mesei keretek között: irányíthat, taníthat, befolyásolhat” (Mátyus, 2020, 37. o.).

Mező Péter Dániel (2020) középiskolás diákok Zrínyi Miklós „Szigeti veszedelem” címû mûvével kapcsolatos reflexióit vizsgálja. „A háborúkról és csatákról szóló irodalmi és történelmi szövegek témája alapvetően kapcsolódik a hadviselés témaköréhez. A háborúknak, csatáknak pedig gyakori velejárója például az ellenfél megfélemlítésén, kifárasztásán stb. - alapuló lélektani hadviselés. Mint Sun $\mathrm{Cu}$ (i.e. IV. század körül élt) harcmúvészeti stratégia írta a Hadviselés mûvészetében: »Nem az az igazán ügyes, aki száz csatában győzni tud, hanem az, aki harc nélkül vesz erōt az ellenségen!«" - írja Mezô Péter Dániel (2020, 45. o.).

Nagy (2020) Görgey Artúr testvérének Görgey Istvánnak a fivérét védő tevékenységeire fókuszál. „Tanulmányom és a prezentációm Görgey István legkorábbi munkáját vonja vizsgálat alá, amelyet testvére, Görgei Artúr rehabilitálása érdekében írt meg. A munka az 1848-as móri csatára vonatkozik, amely után Perczel Mór azzal vádolta Görgei Artúrt, hogy cserbenhagyta ôt, és ennek volt köszönhető az ő veresége. E vád megcáfolása érdekében ragadott tollat Görgey István, és lépett bele ez által egy új szerepbe, a történetíró szerepébe. Munkám tehát egy »self-made« történetíró első szárnypróbálgatásait vizsgálja a móri csatára, és a Görgei
Artúrt ért vádakra vonatkozóan" (Nagy, 2020, 52. o.).

Pavlovics (2020, 50. o.) felveti, hogy egyszemélyes háborúként is értelmezhető a prométheuszi magatartás: „Bár a hadviselés szó hallatán alapvetően hadseregekre gondolunk, Prométheusz esetét is értelmezhetjük hadviselésként átvitt értelemben, mivel szembeszáll az istenekkel."

Sebők (2020) a munkásőrség megszervezésének kezdeti körülményeit kutatja. Megjegyzi, hogy: „A kommunista hatalom által 1957-ben felállított Munkásőrséget nyílt fegyveres harcban sohasem vetették be. Jóval nagyobb volt viszont a lélektani hadviselés terén betöltött szerepe, hiszen az önkéntesekből álló fegyveres szervezetet azért hozták létre, hogy egy újabb, 1956-hoz hasonló megmozdulás esetén a hithű kommunisták kezében is legyen fegyver, akik csírájában el tudnak fojtani bármilyen szervezkedést. A pártállam ugyanis csalódott a hagyományos fegyveres erők megbízhatóságában" (Sebők, 2020, 59. o.).

Tóth (2020) kutatásának középpontjában szűkebb értelemben az impresszionizmus, tágabb értelemben a művészet áll. „Válságos helyzetekben fontos a médiatudatosság, ugyanis az internet lehetőséget ad a hamis információk terjedésének. A gyermekeknek meg kell tanulni fenntartásokkal kezelni ezeket. Kreativitásunk, belső képvilágunk fejlettségével elménk friss maradhat, könnyebben átvészelhetünk váratlan eseményeket. Az érzelmi intelligencia szükségessége sem elhanyagolható: maradjunk emberségesek embertelen helyzetekben is. Továbbá hadviselés, világválság, személyes válság következményeképp 
fellépő lelki sebekre a művészetterápia gyógyírként szolgálhat." (Tóth (2020, 66. o.).

Varga Imre Solt (2020) Luxemburgi Zsigmond huszita hadjáratainak (1420-1422 közötti) első felét, illetve azokat a földrajzi tényezőket kutatja, melyek meghatározók lehettek a hadjáratok alakulásában. E téma erôsen kötődik a történelem, a földrajz és a hadtudományokhoz.

\section{A „Család, közösség, jog és gazdaság”} (Family, Community, Law and Economy) szekció előadóinak reflexiói:

Mező Lilla Dóra (2020) a ghánai nők helyzetében az elmúlt években bekövetkező változásokat elemzi. Meglátása szerint: „A közvélemény és közhangulat befolyásolása a lélektani hadviselés egyik központi témája, amit Ghánai utazásom során is tapasztalhattam például a születésszabályozás és családtervezés témájú plakátok, hirdetések esetében."

Virág (2020) a szociális szövetkezetek megszűnéséhez vezető okok feltárására törekszik. A szociális szövetkezetek múködési sajátosságai és a lélektani hadviselés közötti fő kapcsolódási pontként a közösségeket jelöli meg: „,..mindkét jelenség a közösségekkel együtt értelmezhető. A szövetkezet működésének is egyik alapfeltétele (ami a lélektani hadviselésre is igaz), hogy kölcsönös kötődések alakuljanak ki. A szövetkezeti munkavállaló akkor érzi biztonságban magát, ha a körülötte lévő (vele hasonló hatáskörrel rendelkező) munkavállalóval, minél jobban azonosul és közös célok jellemzik: a szövetkezet minél hatékonyabb mûködtetése. (...) ...ha a kölcsönös kötődések fellazulnak létre- jön egy általános feszültségállapot, mely kedvezőtlenül hat a mindennapi múködésre.” írja Virág (2020, 72. o.).

\section{Zárógondolatok}

A hadviselés és a lélektani hadviselés minden tudomány- és művészet felől megközelíthető témát nyújthat kutatóknak, mûvészeknek egyaránt. Az V. nemzetközi Interdiszciplináris Konferencia kapcsán a témával kapcsolatban nyújtott asszociációk (legalább részben, demonstráció-értékű módon) alátámasztják ezt. Másrészt a várthoz képes szignifikánsan kisebb asszociációk száma jelzi, hogy hasonló, konferenciához kötődő adatgyűjtések alkalmával egyrészt a holista, multi- és interdiszciplináris megközelítésre célszerū példákat adni (akár jelen tanulmányon keresztül is), másrészt a szervezőknek a válaszadásra motiváló megoldásokat kell találniuk.

\section{Irodalom}

Baksa Viktória, Ujlaki Evelin, Tóth Dominika Adelina és Szigeti-Turáni Melinda (2020): Szén nanocsövek aggregációjának hatásai a cornea regenerációja során. In: Mező Ferenc (szerk.): V. Nemzetközi Interdiszciplináris Konferencia: Nyilvános kérdések és válaszok gyüiteménye. 8. o. Letöltés: 2020.04.23. Web: https://drive.google. com/file/d/1xqrgPzC9uxoX7DNK71IE OUC3My-ZBAP2/view

Csontos Fruzsina (2020): Az alsó végtag sérülés-mintái és izomnyújthatósági vizsgálata labdarúgók és vízilabdázók körében. In: Mező Ferenc (szerk.): $V$. 
Nemzetközi Interdiszciplináris Konferencia: Nyilvános kérdések és válaszok gyüjteménye. 13. o. Letöltés: 2020.04.23. Web: https:// drive.google.com/file/d/1xqrgPzC9uxoX 7DNK71IEOUC3My-ZBAP2/view

Csukonyi Csilla és Papp Dávid (2020): Sportpszichológus vagy esportpszichológus? A sportpszichológia szerepe az esportban. In: Mező Ferenc (szerk.): V. Nemzetközi Interdiszciplináris Konferencia: Nyilvános kérdések és válaszok gyüjteménye.14. o. Letöltés: 2020.04.23. Web: https://drive. google.com/file/d/1xqrgPzC9uxoX7DN K71IEOUC3My-ZBAP2/view

Egu, John, Kalmár, József and Király, Gabor (2020): Controlled release of Methotrexate from functionalized Silica-gelatin Aerogel Microparticles applied against Tumor Cell Growth. In: Mező Ferenc (szerk.): V. Nemzetközi Interdiszciplináris Konferencia: Nyilvános kérdések és válaszok gyüjteménye. 15. o. Letöltés: 2020.04.23. Web: https://drive.google.com/file/d/ 1xqrgPzC9uxoX7DNK71IEOUC3MyZBAP2/view

Fábián Fruzsina és Varga Boglárka (2020): Tanulásban akadályozott gyermekek vizsgálata zenei területen. In: Mező Ferenc (szerk.): V. Nemzetközi Interdiszciplináris Konferencia: Nyilvános kérdések és válaszok gyűjteménye. 16. o. Letöltés: 2020.04.23. Web: https://drive.google. com/file/d/1xqrgPzC9uxoX7DNK71IE OUC3My-ZBAP2/view

Gyenes Dominik (2020): Csökkent izomregeneráció Mer Tirozin Kináz hiányos egér modellben. In: Mező Ferenc (szerk.): V. Nemzetközi Interdiszciplináris Konferencia: Nyilvános kérdések és válaszok gyüjteménye. 19. o. Letöltés: 2020.04.23. Web: https:// drive.google.com/file/d/ 1xqrgPzC9uxoX7DNK71IEOUC3MyZBAP2/view

Hinnah Barbara (2020): TGF- $\beta$ útvonal változása Alzheimer-kórban. In: Mező Ferenc (szerk.): V. Nemzetközi Interdiszciplináris Konferencia: Nyilvános kérdések és válaszok gyüjteménye. 22. o. Letöltés: 2020.04.23. Web: https://drive.google. com/file/d/1xqrgPzC9uxoX7DNK71IE OUC3My-ZBAP2/view

Horváth László (2020): A Csáti Refi program tapasztalatai. In: Mező Ferenc (szerk.): V. Nemzetközi Interdiszciplináris Konferencia: Nyilvános kérdések és válaszok gyüjteménye. 24. o. Letöltés: 2020.04.23. Web: https://drive.google.com/file/d/ 1xqrgPzC9uxoX7DNK71IEOUC3MyZBAP2/ view

Kovács Zsófia Dóra (2020): Erényelméletek, avagy visszatérés Arisztotelészhez az ítélkezéselméletben. In: Mező Ferenc (szerk.): V. Nemzetközi Interdiszciplináris Konferencia: Nyilvános kérdések és válaszok gyüjteménye. 28. o. Letöltés: 2020. 04.23. Web: https://drive.google. com/ file/d/1xqrgPzC9uxoX7DNK71I EOUC3My-ZBAP2/view

Krek Norbert (2020): Egy letűnt műfaj újjáéledése - A klasszikus szerepjáték múfaji konvencióinak alakulása a kétezres években. In: Mező Ferenc (szerk.): $V$. Nemzetközi Interdiszciplináris Konferencia: Nyilvános kérdések és válaszok gyüjteménye. 30. o. Letöltés: 2020.04.23. Web: https:// drive.google.com/file/d/1xqrgPzC9uxoX 7DNK71IEOUC3My-ZBAP2/view 
Lengyel Erik (2020): Prelüd műfajának kiteljesedése marimba darabokban. In: Mező Ferenc (szerk.): V. Nemzetközi Interdiszciplináris Konferencia: Nyilvános kérdések és válaszok gyüjteménye. 31. o. Letöltés: 2020.04.23. Web: https://drive.google. com/file/d/1xqrgPzC9uxoX7DNK71IE OUC3My-ZBAP2/view

Lepp Kitti és Némethné Gyurcsik Zsuzsanna (2020): Scapularis diszfunkció és a törzsalsóvégtag stabilitásának vizsgálata, intervenciója a kosárlabdázók körében. In: Mező Ferenc (szerk.): V. Nemzetközi Interdiszciplináris Konferencia: Nyilvános kérdések és válaszok gyüjteménye. 32. o. Letöltés: 2020.04.23. Web: https://drive.google. com/file/d/1xqrgPzC9uxoX7DNK71IE OUC3My-ZBAP2/view

Mátyus Magdolna: „Kettős tükör” : A mese és a gyermeki lélek In: Mező Ferenc (szerk.): V. Nemzetkö̈zi Interdiszciplináris Konferencia: Nyilvános kérdések és válaszok gyüjteménye. 37. o. Letöltés: 2020.04.23. Web: https:// drive.google.com/file/d/1xqrgPzC9 uxoX7DNK71IEOUC3My-ZBAP2/view

Mező Ferenc (2020): Innovációs Stúdium In:

Mező Ferenc (szerk.): V. Nemzetközi Interdiszciplináris Konferencia: Nyilvános kérdések és válaszok gyüjteménye. 39. o. Letöltés: 2020.04.23. Web: https://drive.google. com/file/d/1xqrgPzC9uxoX7DNK71IE OUC3My-ZBAP2/view

Mező Ferenc és Mező Katalin (2020): S.M.ART - School, Measurement and Art (A new innovative measurement system of pupils' cognitive and non-cognitive characteristics). In: Mező Ferenc (szerk.): $V$. Nemzetközi Interdiszciplináris Konferencia: Nyilvános kérdések és válaszok gyüjteménye. 40. o. Letöltés: 2020.04.23. Web: https:// drive.google.com/file/d/1xqrgPzC9uxoX 7DNK71IEOUC3My-ZBAP2/view

Mező Katalin (2020): Hölgyek a tudományban. In: Mező Ferenc (szerk.): $V$. Nemzetközi Interdiszciplináris Konferencia: Nyilvános kérdések és válaszok gyüjteménye. 41. o. Letöltés: 2020.04.23. Web: https:// drive.google.com/file/d/1xqrgPzC9uxoX 7DNK71IEOUC3My-ZBAP2/view

Mező Katalin és Mező Péter Dániel (2020): Az V. Nemzetközi Interdiszciplináris Konferencia a hadviselést, lélektani hadviselést is érintette. Lélektan és hadviselés interdiszciplináris folyóirat, II. évf. 2020/1. szám. 111-112.

Mező Kristóf Szíriusz (2020): A jövő autói. In: Mező Ferenc (szerk.): V. Nemzetközi Interdiszciplináris Konferencia: Nyilvános kérdések és válaszok gyüjteménye. 42. o. Letöltés: 2020.04.23. Web: https://drive.google. com/file/d/1xqrgPzC9uxoX7DNK71IE OUC3My-ZBAP2/view

Mező Lilla Dóra (2020): „Változnak az idők”: a nők helyzete Ghánában. In: Mező Ferenc (szerk.): V. Nemzetközi Interdiszciplináris Konferencia: Nyilvános kérdések és válaszok gyüjteménye. 44. o. Letöltés: 2020.04.23. Web: https://drive.google. com/file/d/ 1xqrgPzC9uxoX7DNK71IEOUC3MyZBAP2/view

Mező Péter Dániel (2020): Zrínyi Miklós: Szigeti veszedelem In: Mező Ferenc (szerk.): V. Nemzetközi Interdiszciplináris Konferencia: Nyilvános kérdések és válaszok gyüjteménye. 45. o. Letöltés: 2020.04.23. Web: https://drive.google.com/file/d/ 1xqrgPzC9uxoX7DNK71IEOUC3MyZBAP2/view 
Molnár Alexandra (2020): Motiváló módszerek a tanulásban akadályozott gyermekek tanítása során. In: Mező Ferenc (szerk.): V. Nemzetközi Interdiszciplináris Konferencia: Nyilvános kérdések és válaszok gyüjteménye. 46. o. Letöltés: 2020.04.23. Web: https:// drive.google.com/file/d/ 1xqrgPzC9uxoX7DNK71IEOUC3MyZBAP2/view

Nagy Kristóf (2020): Görgey István tevékenysége testvére, Artúr védelmében. Az első tanulmány: a móri csata. In: Mező Ferenc (szerk.): V. Nemzetközi Interdiszciplináris Konferencia: Nyilvános kérdések és válaszoke gyüjteménye. 52. o. Letöltés: 2020.04.23. Web: https://drive. google.com/file/d/1xqrgPzC9uxoX7DN K71IEOUC3My-ZBAP2/view

Pavlovics Zsófia (2020): A prométheuszi magatartás camus-i értelmezése In: Mező Ferenc (szerk.): V. Nemzetközi Interdiszciplináris Konferencia: Nyilvános kérdések és válaszok gyüjteménye. 50. o. Letöltés: 2020.04.23. Web: https://drive.google. com/file/d/1xqrgPzC9uxoX7DNK71IE OUC3My-ZBAP2/view

Polyák Lenke (2020): Újonnan szintetizált nukleozid analógok citotoxikológiai vizsgálata. In: Mező Ferenc (szerk.): $V$. Nemzetközi Interdiszciplináris Konferencia: Nyilvános kérdések és válaszok gyüjteménye. 52. o. Letöltés: 2020.04.23. Web: https://drive.google.com/file/d/1xqrg PzC9uxoX7DNK71IEOUC3MyZBAP2/view

Pšenáková Ildikó (2020a): Ne hagyd magad becsapni! In: Mező Ferenc (szerk.): $V$. Nemzetközi Interdiszciplináris Konferencia: Nyilvános kérdések és válaszok gyüjteménye. 53. o. Letöltés: 2020.04.23. Web: https:// drive.google.com/file/d/1xqrgPzC9 uxoX7DNK71IEOUC3My-ZBAP2/view Pšenáková, Ildikó (2020b): Ne hagyd magad becsapni! Lélektan és hadviselés interdiszciplináris folyóirat, II. évf. 2020/1. szám. 55-65. doi: 10.35404/LH.2020.1.55

Roskó Tibor (2020): Mesterséges intelligencia fejlesztések három év távlatában. In: Mező Ferenc (szerk.): V. Nemzetközi Interdiszciplináris Konferencia: Nyilvános kérdések és válaszok gyüjteménye. 54 . o. Letöltés: 2020.04.23. Web: https://drive. google.com/file/d/1xqrgPzC9uxoX7DN K71IEOUC3My-ZBAP2/view

Sáfrány Judit (2020a): Szorongásos tünetegyüttes az iskolai környezetben. In: Mező Ferenc (szerk.): V. Nemzetközi Interdiszciplináris Konferencia: Nyilvános kérdések és válaszok gyüjteménye. 55. o. Letöltés: 2020.04. 23. Web: https://drive.google. com/file/d/1xqrgPzC9uxoX7DNK71IE OUC3My-ZBAP2/view

Sáfrány, Judit (2020b): Anxiety disorders and academic achievement. In: Mező Ferenc (szerk.): V. Nemzetközi Interdiszciplináris Konferencia: Nyilvános kérdések és válaszok gyüjteménye. 56. o. Letöltés: 2020.04.23. Web: https://drive.google.com/file/d/ 1xqrgPzC9uxoX7DNK71IEOUC3MyZBAP2/view

Sebők Balázs: „Enni, inni tudunk, de gyakorlatot végrehajtani nem". A Munkásőrség felállításának kezdeti nehézségei Szolnok megyében. In: Mező Ferenc (szerk.): $V$. Nemzetközi Interdiszciplináris Konferencia: Nyilvános kérdések és válaszok gyüjteménye. 59. o. Letöltés: 2020.04.23. Web: https:// 
drive.google.com/file/d/1xqrgPzC9uxoX 7DNK71IEOUC3My-ZBAP2/view

Szatmári Roland (2020): Száradásos repedezés vizsgálata. In: Mező Ferenc (szerk.): $V$. Nemzetközi Interdiszciplináris Konferencia: Nyilvános kérdések és válas zok gyüjteménye. 61. o. Letöltés: 2020.04.23. Web: https:// drive.google.com/file/d/1xqrgPzC9uxoX 7DNK71IEOUC3My-ZBAP2/view

Tóth Lilla (2020): Megragadható pillanatok az impressziók hullámaiban. In: Mező Ferenc (szerk.): V. Nemzetközi Interdiszciplináris Konferencia: Nyilvános kérdések és válaszok gyüjteménye. 66. o. Letöltés: 2020.04.23. Web: https://drive.google.com/file/d/ 1xqrgPzC9uxoX7DNK71IEOUC3MyZBAP2/view

Uzonyi Noémi (2020): An empirical study of Taylor's power law in random graph models and real networks. In: Mező Ferenc (szerk.): V. Nemzetközi Interdiszciplináris Konferencia: Nyilvános kérdések és válaszok gyüjteménye. 68. o. Letöltés: 2020.04.23. Web: https://drive.google. com/file/d/1xqrgPzC9uxoX7DNK71IE OUC3My-ZBAP2/view

Varga Imre Solt (2020): Luxemburgi Zsigmond huszita hadjáratainak első fele (1420-1422) és a hadjáratokat befolyásoló földrajzi tényezők. In: Mező Ferenc (szerk.): V. Nemzetközi Interdiszciplináris
Konferencia: Nyilvános kérdések és válaszok gyüjteménye. 70. o. Letöltés: 2020.04.23. Web: https://drive.google.com/file/d/ 1xqrgPzC9uxoX7DNK71IEOUC3MyZBAP2/view

Varga-Csikász Csenge (2020): A drámapedagógia hatása a tanári kompetenciák alakulására. In: Mező Ferenc (szerk.): $V$. Nemzetközi Interdiszciplináris Konferencia: Nyilvános kérdések és válaszok gyüjteménye. 71. o. Letöltés: 2020.04.23. Web: https:// drive.google.com/file/d/1xqrgPzC9uxoX 7DNK71IEOUC3My-ZBAP2/view

Virág Ádám (2020): A szociális szövetkezetek megszűnése mögött álló háttértényezők. In: Mező Ferenc (szerk.): V. Nemzetközi Interdiszciplináris Konferencia: Nyilvános kérdések és válaszok gyüjteménye. 72. o. Letöltés: 2020.04.23. Web: https://drive.google. com/file/d/1xqrgPzC9uxoX7DNK71IE OUC3My-ZBAP2/view

Zsemján Eszter (2020): A tanulásban akadályozottak integrált, inkluzív nevelése, oktatása Szabolcs-Szatmár-Bereg Megyében. In: Mező Ferenc (szerk.): $V$. Nemzetközi Interdiszciplináris Konferencia: Nyilvános kérdések és válaszok gyüjteménye. 75. o. Letöltés: 2020.04.23. Web: https:// drive.google.com/file/d/1xqrgPzC9uxoX 7DNK71IEOUC3My-ZBAP2/view 